\title{
Peningkatan Keterampilan Kerjasama Peserta Didik melalui Penerapan Model Group Investigation
}

\section{Improvement of Student's Teamwork Skills through the Application of Group Investigation Model}

\author{
Noviana Ika Puspitasari $^{1 *}$, Yudi Rinanto ${ }^{1}$, Sri Widoretno ${ }^{1}$ \\ ${ }^{1}$ Pendidikan Biologi FKIP UNS, Surakarta, Indonesia \\ *Corresponding authors: novianaika_11@yahoo.com
}

Manuscript received: ......... Revision accepted:

\begin{abstract}
The research aimed to improve student's teamwork skills through the application of Group Investigation model. The research was a Classroom Action Research that performed within 2 cycles used Group Investigation (GI) model. The research partisipans were 36 students of XI MIA 4 SMA N Colomadu Karanganyar academic year 2015/2016. The research data consisted 12 indicators teamwork skills include the group's goals, trust and conflict, reaction of differences, leadership, control and procedures, utilisation of resources, interpersonal communication, listening, flow of communication, problem solving, experimentation and creativity, and evaluation that collected through observation, interview, and documentation. The validity of the data used technique of triangulation method. The research used qualitative descriptive analysis techniques. The results showed an increase that varies on each indicators. Thus, the application of Group Investigation model can improved student's teamwork skills.
\end{abstract}

Keywords: Teamwork Skill, Group Investigation

\section{PENDAHULUAN}

Kerjasama atau kolaborasi antar pe-serta didik merupakan salah satu keteram-pilan yang mampu mengaitkan keterampilan-keterampilan lain seperti berpikir kritis, motivasi, dan metakognisi (Lai \& Viering, 2012), sehingga keterampilan peserta didik dalam bekerjasama diperlukan untuk menghadapi pembelajaran pada abad 21 (P21, 2009). Kerjasama kelompok menurut Lai (2011) diartikan sebagai keterlibatan peserta didik dalam memecahkan masalah secara bersama-sama untuk mencapai tujuan bersama. Keterampilan kerjasama diklasi-fikasikan berdasarkan 12 indikator yang meli-puti tujuan kelompok, kepercayaan dan konflik, reaksi terhadap perbedaan, kepemim-pinan, kontrol dan prosedur, penggunaan sumber daya, komunikasi interpersonal, mendengarkan, alur komunikasi, pemecahan masalah, percobaan dan kreativitas, serta evaluasi (Crebert, et al., 2011).

Analisis keterampilan kerjasama peserta didik pada prasiklus adalah tujuan kelompok $14,81 \%$, kepercayaan dan konflik 40,74\%, reaksi terhadap perbedaan $59,26 \%$, kepemimpinan 40,74\%, kontrol dan prosedur 40,74\%, penggunaan sumber daya $22,22 \%$, komunikasi interpersonal 40,74\%, mende-ngarkan 55,56\%, alur komunikasi 44,44\%, pemecahan masalah 40,74\%, percobaan dan kreativitas $37,04 \%$, serta evaluasi $11,11 \%$. Hasil analisis data menunjukan keterampilan kerjasama peserta didik perlu ditingkatkan.

Upaya peningkatan keterampilan kerjasama dilakukan dengan menerapkan model pembelajaran yang memfasilitasi peserta didik untuk bekerjasama (Nata, 2009). Pembelajaran kooperatif menuntut peserta didik untuk bekerja sama dalam kelompok-kelompok kecil (Majid, 2013), saling berbagi informasi, dan saling mendukung dalam penyelesaian tugas (Barkley, et al., 2012). Model GI diterapkan karena adanya tugas akademik yang menuntut peserta didik saling bekerjasama dalam menguasai, menganalisis, dan menyintesis informasi untuk menye-lesaikan suatu permasalahan dalam tugas yang diperoleh (Slavin, 2009). Model GI terdiri dari enam tahapan yang telah ditetapkan oleh Sharan yaitu tahap pemilihan topik, tahap perencanaan kooperatif, tahap implementasi, tahap analisis dan sintesis, tahap mempre-sentasikan hasil akhir, dan tahap evaluasi (Majid, 2013).

Tahap pertama adalah pemilihan topik yang berupa peserta didik dipandu oleh guru menentukan topik dan memilih subtopik untuk diidentifikasi (Jacobsen, et al., 2009). Tahap kedua adalah perencanaan kooperatif yang berupa peserta didik mengembangkan berbagai rumusan masalah dari subtopik yang telah dipilih untuk membantu peserta didik dalam melakukan penyelidikan. Pada tahap peren-canaan kooperatif, peserta didik diberikan kesempatan membagi tugas untuk masing-masing anggota dalam kelompok (Slavin, 2009). Tahap ketiga adalah tahap implementasi. Pada tahap implementasi, peserta didik melakukan rencana kegiatan yang telah dibuat (Jacobsen et al., 2009). Tahap keempat merupakan tahap analisis dan sintesis. Pada tahap analisis dan sintesis setiap anggota kelompok menganalisis dan mengolah infor-masi yang telah diperoleh dari kegiatan penyelidikan (Jacobsen et al.,2009). Tahap kelima adalah tahap mempresentasikan laporan akhir. Pada kegiatan presentasi 
dibutuhkan peran pendengar untuk mengevaluasi presentasi dari kelompok yang mempresentasikan hasil penyelidikannya (Slavin, 2009). Tahap keenam merupakan tahap evaluasi. Pada tahap evaluasi, peserta didik membandingkan penemuannya dengan penemuan dari kelompok lain serta men-diskusikan persamaan dan perbedaan antar temuan (Jacobsen, et al., 2009).

Penelitian bertujuan meningkatkan keterampilan kerjasama peserta didik melalui penerapan model GI di kelas XI MIA 4 SMA N Colomadu Karanganyar tahun pelajaran 2015/2016.

\section{METODE PENELITIAN}

Metode penelitian menggunakan Penelitian Tindakan Kelas dengan model spiral yang dikembangkan oleh Stephen Kemmis dan Robin Mc Taggart. Penelitian Tindakan Kelas merupakan penelitian yang bertujuan untuk membantu guru menemukan strategi terbaik dalam mengajar sehingga mampu meningkatkan pemahaman peserta didik (Mettetal, 2001). Model spiral memiliki 4 tahapan, yaitu: perencanaan, Pelaksanaan, Pengamatan, dan refleksi (Sugiyono, 2013).

Subyek penelitian adalah peserta didik kelas XI MIA 4 SMA N Colomadu Karanganyar pada semester genap tahun ajaran 2015/2016. Jumlah keseluruhan obyek penelitian sebanyak 36 peserta didik yang terdiri dari 17 peserta didik laki-laki dan 19 peserta didik perempuan.

Data penelitian berupa keterampilan kerjasama peserta didik yang diobservasi selama proses pembelajaran dengan menggu-nakan model GI. Pengumpulan data peneliti-an melalui metode observasi, wawancara, dan dokumentasi. Validasi data menggunakan teknik triangulasi metode. Teknik triangulasi metode merupakan teknik pengolahan data hasil penelitian yang diperoleh dengan membandingkan berbagai metode yang berbeda untuk menarik suatu kesimpulan (Mills, 2011). Analisis data menggunakan teknik deskriptif kualitatif yang terdiri dari reduksi data, penyajian data, dan penarikan kesimpulan atau verifikasi.

\section{HASIL DAN PEMBAHASAN}

Hasil penelitian berupa keterampilan kerjasama peserta didik yang meliputi aspek tujuan kelompok, kepercayaan dan konflik, reaksi terhadap perbedaan, kepemimpinan, kontrol dan prosedur, penggunaan sumber daya, komunikasi interpersonal, mendengar-kan, alur komunikasi, pemecahan masalah, percobaan dan kreativitas, serta evaluasi selama proses pembelajaran dengan menggunakan model $G I$.

\section{Siklus 1}

Hasil tindakan siklus 1 berupa capaian indikator keterampilan kerjasama peserta didik yang diperoleh melalui penerapan model GI pada materi sistem ekskresi dengan sub topik faktor - fakor yang mempengaruhi proses pengeluaran keringat. Hasil analisis keterampilan kerjasama peserta didik pada siklus 1 disajikan pada Gambar 1.

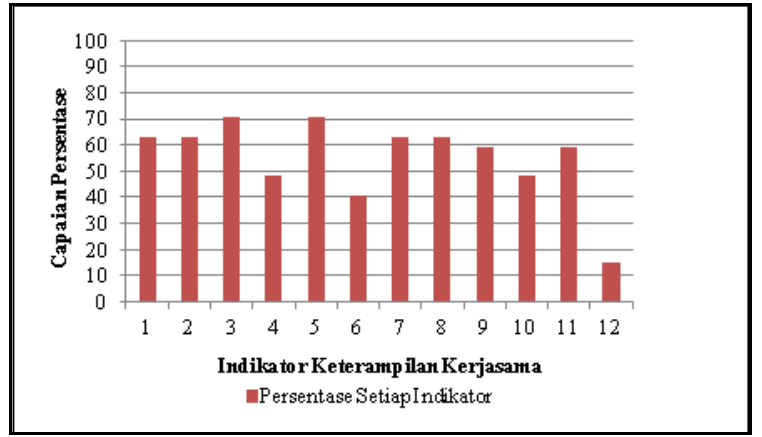

Gambar 1. Capaian Persentase Indikator Keterampilan Kerjasama Peser-ta Didik pada Siklus 1

Gambar 1 menunjukkan hasil analisis capaian setiap indikator keterampilan kerjasama yang meliputi indikator 1 tujuan kelompok $62,96 \%$, indikator 2 kepercayaan dan konflik $62,96 \%$, indikator 3 reaksi terhadap perbedaan $70,337 \%$, indikator 4 kepemimpinan $48,15 \%$, indikator 5 kontrol dan prosedur $70,37 \%$, indikator 6 penggunaan sumber daya 40,74\%, indikator 7 komunikasi interpersonal $62,96 \%$, indikator 8 mendengarkan $62,96 \%$, indikator 9 alur komunikasi $59,26 \%$, indikator 10 pemecahan masalah $48,15 \%$, indikator 11 percobaan dan kreativitas 59,26\%, serta indikator 12 evaluasi $14,81 \%$.

\section{Siklus 2}

Hasil tindakan siklus 2 berupa capaian indikator keterampilan kerjasama Peserta didik yang diperoleh melalui penerapan model GI pada materi sistem ekskresi dengan sub topik kelainan pada urin dan kaitannya dengan penyakit. Hasil analisis keterampilan kerjasama kelompok peserta didik pada siklus 2 disajikan pada Gambar 2.

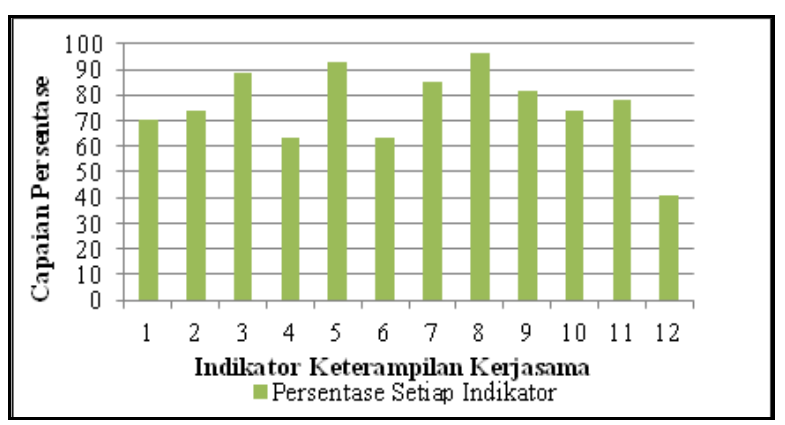

Gambar 2. Capaian Persentase Indikator Keterampilan Kerjasama Peser-ta Didik pada Siklus 2

Gambar 2 menunjukkan hasil analisis capaian setiap indikator keterampilan kerjasama yang meliputi indikator 1 tujuan kelompok 70,37\%, indikator 2 kepercayaan dan konflik 74,07\%, indikator 3 reaksi terhadap perbedaan $88,89 \%$, indikator 4 kepemimpinan $62,96 \%$, indikator 5 kontrol dan prosedur $92,59 \%$, indikator 6 penggunaan sumber daya 62,96\%, indikator 7 komunikasi interpersonal $85,19 \%$, indikator 8 mendengarkan $96,30 \%$, indikator 9 alur komunikasi $81,48 \%$, indikator 10 pemecahan masalah $74,07 \%$, indikator 11 percobaan dan kreativitas $77,78 \%$, serta indikator 12 evaluasi $40,74 \%$.

\section{Perbandingan Semua Siklus}


Perbandingan hasil analisis capaian setiap indikator keterampilan kerjasama peserta didik dari kegiatan prasiklus, siklus 1 , dan siklus 2 mengalami peningkatan yang berbeda-beda. Ketercapaian setiap indikator disajikan pada Gambar 3.

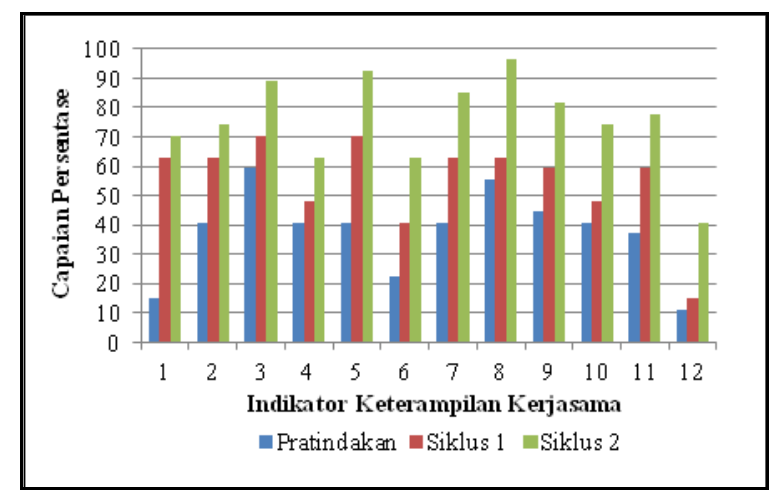

Gambar 3. Capaian Persentase Indikator Keterampilan

Kerjasama Peser-ta Didik pada Prasiklus, Siklus 1, dan Siklus 2

Indikator 1 (tujuan kelompok) memiliki persentase sebesar $14,81 \%$ pada prasiklus dan meningkat sebesar $48,15 \%$ pada siklus 1 menjadi $62,96 \%$, kemudian meningkat lagi sebesar $7,41 \%$ pada siklus 2 menjadi $70,37 \%$. Peningkatan indikator tujuan kelompok melalui penerapan model GI didukung oleh Tseng dan Yeh (2013) yang menyatakan bahwa pembelajaran kooperatif mendorong peserta didik bekerjasama dalam kelompok untuk mencapai tujuan bersama.

Indikator 2 (kepercayaan dan konflik) memiliki persentase sebesar $40,74 \%$ pada prasiklus dan meningkat sebesar $22,22 \%$ pada siklus 1 menjadi $62,96 \%$, kemudian meningkat lagi sebesar $11,11 \%$ pada siklus 2 menjadi $74,07 \%$. Peningkatan indikator kepercayaan dan konflik melalui penerapan model GI didukung oleh pendapat Laal dan Ghodsi (2012) menyatakan bahwa pembelajaran kooperatif mampu menciptakan lingkungan yang mendukung peserta didik untuk mencari solusi dari suatu permasalahan tanpa ada persaingan antar individu atau antar kelompok karena peserta didik dituntut untuk bertanggung jawab terhadap setiap anggota lain dalam kelompok.

Indikator 3 (reaksi terhadap perbedaan) memiliki persentase sebesar $59,26 \%$ pada pratindakan dan meningkat sebesar $11,11 \%$ pada siklus 1 menjadi $70,37 \%$, kemudian meningkat lagi sebesar $18,52 \%$ pada siklus 2 menjadi $88,89 \%$. Peningkatan indikator reaksi terhadap perbedaan melalui penerapan model GI didukung oleh Laal dan Ghodsi (2012) yang menyatakan bahwa pembelajaran kooperatif membantu peserta didik untuk menyelesaikan perbedaan dengan menyanggah pendapat anggota lain dan berusaha mempertahankan pendapat tanpa memaksakan pendapatnya sendiri.

Indikator 4 (kepemimpinan) memili-ki persentase sebesar $40,74 \%$ pada prasiklus dan meningkat sebesar $7,41 \%$ pada siklus 1 menjadi $48,15 \%$, kemudian meningkat lagi sebesar $14,81 \%$ pada siklus 2 menjadi $62,96 \%$. Peningkatan indikator kepemimpi-nan melalui penerapan model GI didukung dengan pendapat Rao, et al. (2002) yang menyatakan bahwa dalam penerapan pembelajaran kooperatif, peserta didik mendapatkan kesempatan terlibat dalam kerja kelompok untuk menyelesaikan suatu tugas atau mendiskusikan suatu permasalahan, sehingga peserta didik dituntut untuk memiliki sikap kepemimpinan. Kepemimpi-nan bukan mengacu kepada satu orang yang terlihat menguasai jalannya kerja kelompok, melainkan kepada anggota yang berbagi pendapat atau ide dan berperan dalam pembagian tugas kelompok (Thomas, et al., 2004).

Indikator 5 (kontrol dan prosedur) memi-liki persentase sebesar $40,74 \%$ pada prasiklus dan meningkat sebesar $29,63 \%$ pada siklus 1 menjadi 70,37\%, kemudian meningkat lagi sebesar $22,22 \%$ pada siklus 2 menjadi $92,59 \%$. Peningkatan indikator kontrol dan prosedur melalui penerapan model GI didukung oleh pendapat Hackman dan Morris (1975) yang menyatakan bahwa kinerja kelompok menjadi lebih efektif dengan pemberian suatu tugas yang dapat mendorong peserta didik untuk merencana-kan dan melaksanakan kerja kelompok.

Indikator 6 (penggunaan sumber daya) memiliki persentase sebesar $22,22 \%$ pada prasiklus dan meningkat sebesar $18,52 \%$ pada siklus 1 menjadi $40,74 \%$, kemudian meningkat lagi sebesar $22,22 \%$ pada siklus 2 menjadi $62,96 \%$. Peningkatan indikator penggunaan sumber daya melalui penerapan model GI didukung oleh pendapat Laal dan Laal (2012) yang menyatakan bahwa pembelajaran kooperatif menuntut peserta didik untuk mencari dan menerapakan materi pembelajaran, tidak hanya memperhatikan penjelasan materi dari guru. Peserta didik dapat mencari informasi melalui berbagai sumber seperti jurnal, buku, video, dan internet untuk dibagikan kepada anggota lain dalam kegiatan diskusi. Kegiatan pembelajaran menjadi lebih efektif karena peserta didik berinteraksi dengan teman satu kelompok untuk bersama-sama mencari informasi, menyatukan perbedaan pendapat, dan menyelesaikan suatu permasalahan (Reychav \& Wu, 2015).

Indikator 7 (komunikasi interperso-nal) memiliki persentase sebesar $40,74 \%$ pada prasiklus dan meningkat sebesar $22,22 \%$ pada siklus 1 menjadi $62,96 \%$, kemudian meningkat lagi sebesar $22,23 \%$ pada siklus 2 menjadi $85,19 \%$. Peningkatan indikator komunikasi interpersonal melalui penerapan model GI didukung oleh pendapat Rechav dan $\mathrm{Wu}$ (2015) yang menyatakan bahwa pembelajaran kooperatif menuntut keterlibatan peserta didik dalam kelompok-kelompok kecil untuk mengemukakan ide-ide atau pendapat.

Indikator 8 (mendengar) memiliki persentase sebesar $55,56 \%$ pada prasiklus dan meningkat sebesar $7,4 \%$ pada siklus 1 menjadi $62,96 \%$, kemudian meningkat lagi sebesar $33,34 \%$ pada siklus 2 menjadi 96,30\%. Peningkatan indikator mendengar melalui penerapan model GI didukung oleh pendapat Isjoni (2011) yang menyatakan bahwa peserta didik dituntut untuk menciptakan suasana demokratis dengan mendengarkan pendapat yang disampaikan oleh anggota lain dalam kelompok ketika pembelajaran kooperatif dilaksanakan. 
Indikator 9 (alur komunikasi) memiliki persentase sebesar $44,44 \%$ pada prasiklus dan meningkat sebesar $14,82 \%$ pada siklus 1 menjadi $59,26 \%$, kemudian meningkat lagi sebesar $22,22 \%$ pada siklus 2 menjadi $81,48 \%$. Indikator alur komunikasi meningkat sejalan dengan indikator mendengar (Crebert, et al., 2011). Aktifitas mendengarkan diperlukan untuk mengetahui kesalahan atau kekurangan dari pendapat yang disampaikan, sehingga peserta didik dapat memberikan tambahan atau solusi melalui kegiatan diskusi (Isjoni, 2011). Pembelajaran kooperatif memberikan kesempatan kepada peserta didik melakukan interaksi secara langsung (tatap muka) untuk berdiskusi (Majid, 2013).

Indikator 10 (pemecahan masalah) memiliki persentase sebesar $40,74 \%$ pada prasiklus dan meningkat sebesar $7,41 \%$ pada siklus 1 menjadi $48,15 \%$, kemudian meningkat lagi sebesar $25,92 \%$ pada siklus 2 menjadi $74,07 \%$. Peningkatan indikator pemecahan masalah melalui penerapan model GI didukung oleh pendapat Laal dan Laal (2012) serta Reychav dan Wu (2015) yang menyatakan bahwa pembelajaran kooperatif melibatkan peserta didik dalm kelompok untuk bekerjasama memecahkan masalah atau tugas yang diberikan.

Indikator 11 (percobaan dan kreatifitas) memiliki persentase sebesar $37,04 \%$ pada prasiklus dan meningkat sebesar 22,22\% pada siklus 1 menjadi 59,26\%, kemudian meningkat lagi sebesar $18,52 \%$ pada siklus 2 menjadi $77,78 \%$. Peningkatan indikator percobaan dan kreatifitas melalui penerapan model GI didukung dengan pendapat Stouffer dan Slavin. Stouffer, et al. (2004) menyatakan bahwa proses kreatifitas merupakan suatu proses untuk menemukan permasalahan atau ketidaksesuaian informasi, mengemukakan ide-ide dari suatu hipotesis, menguji, dan mengomunikasikan hasil akhir.

Indikator 12 (evaluasi) memiliki persentase sebesar $11,11 \%$ pada prasiklus dan meningkat sebesar $3,7 \%$ pada siklus 1 menjadi $14,81 \%$, kemudian meningkat lagi sebesar 25,93\% pada siklus 2 menjadi 40,74\%. Peningkatan indikator evaluasi melalui penerapan model GI didukung dengan pendapat Majid (2013) yang menyatakan bahwa evaluasi proses kelompok merupakan prinsip dari pembelajaran kooperatif yang menuntut guru dan peserta didik melakukan penilaian terhadap kerja kelompok dan hasil kerja peserta didik selama kegiatan belajar mengajar berlangsung.

.Hasil penelitian menunjukan peningkatan yang bervariasi pada setiap indikator keterampilan kerjasama peserta didik. Analisis peningkatan persentase setiap indikator dan didukung dengan berbagai teori yang relevan mengindikasikan adanya peningkatan keterampilan kerjasama kelompok melalui penerapan model GI.

\section{KESIMPULAN}

Penerapan model GI dapat mening-katkan keterampilan kerjasama peserta didik dengan peningkatan persentase yang bervariasi pada setiap indikator keterampilan kerjasama.

\section{DAFTAR PUSTAKA}

Barkley, E. E., Cross, K. P., \& Major, C. H. (2012). Collaborative Learning Techniques. Terj. Narulita Yusron. Bandung: Nusa Media. (Buku asli diterbitkan pada tahun 2005).

Crebert, G., Patrick, C. J., Cragnolini, V., Smith, C., Worsfold, K., \& Webb, F. (2011). Teamwork Skills Toolkit. (Retrieved from the World Wide Web 4th April,

http://www.griffith.edu.au/gihe/resourcessupport /graduate-attributes

Hackman, J. R. \& Morris, C. G. (1975). Group Tasks, Group Interaction Process, and Group Performance Effectiveness: A Review and Proposed Integration. Adrames in Experimental Social Phisychology, Vol 7.

Isjoni. (2009). Pembelajaran Kooperatif: Meningkatkan Kecerdasan Antar Peserta Didik. Yogyakarta: Pustaka Pelajar.

Jacobsen, D. A., Eggen, P., \& Kauchak, D. (2009). Methods for Teaching. Terj. Achmad Fawaid \& Khoirul Anam. Yogyakarta: Pustaka Pelajar.

Laal, M. \& Ghodsi, S. M. (2012). Benefits of Collaborative Learning. Procedia - Social and Behavioral Sciences, Vol 31, 486-490.

Laal, M. \& Laal, M. (2012). Collaborative Learning: What Is It?. Procedia - Social and Behavioral Sciences, Vol 31, 491-495.

Lai, E. R. (2011). Collaboration: A Literature Review. United States of America: Pearson.

Lai, E. R. \& Viering, M (2012). Assessing 21st Century Skills: Integrating Research Findings. United States of America: Pearson.

Majid, A. (2013). Strategi Pembelajaran. Bandung: PT Remaja Rosdakarya.

Mettetal, G. 2001. The What, Why and How of Classroom Action Research. Journal of Scholarship of Teaching and Learning (JoSoTL), 2 (1), 7.

Mills, Geoffrey E. (2011). Action Research: A Guide for the Teacher Researcher. United States of America: Pearson.

Nata, A. (2009). Perspektif Islam tentang Strategi Pembelajaran. Jakarta: Prenada Media Group.

Partnership for 21st Century Skills. (2009). P21 framework definitions. Diperoleh 17 Juli 2015, dari http://www.p21.org/storage/documents/P21 Framework_Definitions.pdf.

Rao, S. P., Collins, H. D., \& DiCarlo, S. E. (2002). Collaborative Testing Enhances Student Learning. Advances In Physiology Education, 26(1), 37-41.

Reychav, I. \& Wu, D. (2015). Mobile Collaborative Learning: The Role of Individual Learning in Groups Through Text and Video Content Delivery in Tablets. Computers in Human Behavior, Vol 50, 520-534.

Slavin, R. E. (2009). Cooperative Learning: Teori, Riset, dan Praktik. Terj. Narulita Yusron. Bandung: Nusa Media.

Stouffer, W. B., Russel, J. S., \& Oliva, M. G. (2004). Making the Strange Familiar: Creativity and the Future of Engineering Education. Proceedings of the 
2004 American Society for Engineering Education Annual Conference \& Exposition.

Sugiyono. (2013). Metode Penelitian Kuantitatif, Kualitatif, dan $R$ \& D. Bandung: Alfabeta.

Thomas, E. J., Sexton, J. B., \& Helmreich, R. L. (2013). Translating Teamwork Behaviours from Aviation to Healthcare: Development of Behavioural Markers Forneonatal Resuscitation. Qual Saf Health Care, Vol 13, 57-64.
Tseng, H. W. \& Yeh, H. T. (2013). Team Member's Perceptions of online Teamwork Learning Experiences and Building teamwork trust: A Qualitative Study. Computers \& Education, Vol 63, $1-9$. 